\title{
MENINGKATKAN PEMAHAMAN PERAWAT TERKAIT DIAGNOSA KEPERAWATAN PADA PASIEN DI RUMAH SAKIT
}

\author{
Dwi Syafriningsih
}

\section{Email : dwisyafriningsih@gmail.com}

\section{LATAR BELAKANG}

Keperawatan adalah bagian yang tidak dapat di pisahkan dari upaya pelayanan kesehatan secara keseluruhan. Keperawatan merupakan ilmu yang berkenaan dengan masalah-masalah fisik, psikologis, sosiologis, budaya dan spiritual dari individu (Depkes RI,1996).

Asuhan keperawatan merupakan suatu proses keperawatan yaitu suatu metode sistematis dan ilmiah yang digunakan perawat untuk memenuhi kebutuhan pasien dalam mencapai atau mempertahankan keadaan biologis, psikologis, sosial dan spiritual yang optimal melalui tahapan pengkajian keperawatan, indentifikasi diagnosa keperawatan, penentuan perencanaan keperawatan, melaksanakan tindakan keperawatan serta mengevaluasinya (Suarli \& Yahya,2012).

Diagnosa asuhan keperawatan adalah pernyataan yang menjelaskan status atau masalah kesehatan aktual atau potensial serta penyebabnya (Nursalam,2007).

Tujuan diagnosa keperawatan dalam asuhan keperawatan yaitu untuk mengidentifikasi masalah adanya respon klien terhadap status kesehatan, faktor yang menunjang atau menyebabkan suatu masalah, kemampuan pasien untuk mencegah atau menyelesaikan masalah, mengkomunikasikan masalah klien pada tim kesehatan, mendokumentasikan tanggung jawab dalam identifikasi masalah, mengidentifikasi masalah utama perkembangan keperawatan (Nursalam,2007).

Diagnosa keperawatan merupakan suatu kesimpulan yang dihasilkan dari analisa data (Carpenito, 2009). Diagnosa keperawatan adalah langkah kedua dari proses keperawatan yang menggambarkan penilaian klinis tentang respon individu, keluarga, kelompok maupun masyarakat 
terhadap permasalahan kesehatan baik aktual maupun potensial.

Tahap diagnosa adalah tahap pengambilan keputusan dimana pada proses keperawatan meliputi identifikasi apakah masalah klien dapat dihilangkan, dikurangi atau diubah melalui tindakan keperawatan (Nursalam,2007).

Kriteria proses keperawatan meliputi : proses diagnosa terdiri dari atas analisis, interprestasi data, identifikasi masalah, klien dan perumusan diagnosis keperawatan, diagnosa keperawatan terdiri dari atas masalah, penyebab, dan tanda atau gejala, atau terdiri atas masalah dan penyebab, bekerjasama dengan klien, petugas kesehatan lain untuk memvalidasi diagnosa keperawatan, melakukan pengkajian ulang, dan merevisi diagnosa berdasarkan data terbaru (Nursalam2007).

\section{METODE}

Metode dalam penulisan ini menggunakan metode kualitatif, yaitu merupakan metode yang sifatnya memberikan suatu penjelasan dengan analisis. Metode ini bersifat subjektif, yaitu proses penelitian yang lebih fokus pada landasan teori. Metode yang digunakan dalam kajian ini adalah Literature review.

Metode ini menganalisis, eksplorasi dan kajian bebas pada artikel, jurnal, maupun ebook yang releven dan berfokus pada metode pembelajaran klinik yang mempengaruhi kemampuan mahasiswa dalam menentukan diagnosa keperawatan. Adapun artikel yang digunakan pada literature review ini adalah artikel yang didapatkan dengan memuat 3 database Pubmed, Geogle Scholar dan Science Direct.

\section{HASIL}

Menurut hasil dari pencarian beberapa literature, didapatkan bahwa perawat harus mampu memberikan atau membuat perencanaan yang tepat, efisian dan efektif. kefektifan perawat dalam menentukan suatu diagnosa keperawatan akan dapat meningkatkan kinerja perawat yang akan dilakukan dan juga kesejahteraan terhadap pasien. Penentuan diagnosa yang tepat dapat memghasilkan tindakan kesehatan yang tepat juga.

Menentukan diagnosa keperawatan perawat harus menghindari terjadinya kesalahan dalam penalaran diagnostic. Jika perawat salah menentukan suatu diagnosa hal tersebut akan berakibat bagi klien dan klien juga akan merasa tidak nyaman akan pelayanan yang diberikan oleh perawat di rumah sakit tersebut. Pentingnya menentukan diagnosa keperawatan bagi 
klien maka perawat harus dapat meningkatkan pemahaman mengenai diagnosa keperawatan karena dengan diagnosa keperawatanlah yang dapat menghasilkan intervensi yang benar.

Pada saat melakukan pengkajian, perawat harus memperhatikan dan mempertimbangkan kesehatan yang sedang terjadi pada diri klien tersebut. Karena dengan memperhatikan perilaku klien dalam menyelesaikan suatu proses akan mempermudah perawat salam menentukan perumusan diagnosa keperawatan. Apabila suatu proses terjadi, klien harus dapat menyelesaikan sejumlah tahapan sebelum mencapai sasaran. Dengan mengidentifikasi perilaku dan langkah yang dilakukan oleh klien, perawat dapat menilai kemajuan dalam menyelesaikan proses dan menggunakan informasi tersebut untuk merumuskan diagnosa keperawatan.

Perawat perlu melakukan diagnosa secara baik dan aktual, sebelum membuat diagnosa keperawatan, pada saat melakukan pengkajian harus dilakukan dengan baik dan benar sehingga pada saat melakukan pengkajian dapat dilakukan dengan detail untuk membuat perawat membuat diagnosa menjadi lebih aktual dan benar.
Penegakan diagnosis keperawatan sebagai salah satu komponen standar asuhan keperawatan perlu dilaksanakan dengan baik sebagaimana yang diamanahkan dalam undang-undang No.38 tahun 2014 tantang keperawatan pada pasal 30 bahwa dalam menjalankan tugas sebagai pemberi asuhan keperawatan, perawat berwenang menetapkan diagnosis keperawatan. Hal ini menegaskan wewenang perawat sebagai penegak diagnosis yang harus memiliki kemampuan diagnosis yang baik sebagai dasar mengembangkan rencana intervensi keperawatan dalam rangka mencapai peningkatan, pencegahan dan penyembuhan serta pemulihan kesehatan klien.

\section{PEMBAHASAN}

Diagnosa keperawatan adalah suatu kesimpulan yang dihasilkan dari analisa data (Carpenito, 2009). Diagnosa keperawatan adalah penilaian klinik tentang respon individu keluarga, atau komunitas terhadap masalah kesehatan atau proses kehidupan yang aktual atau potensia. Diagnosa keperawatan memberikan dasar untuk pemilhan intervensi keperawatan untuk mencapai hasil yang merupakan tanggung jawab perawat menurut North American Nursing Diagnosis Association (NANDA) (1990, dalam Allen, 1998). 
- Kriteria diagnosa keperawatan Kriteria antara lain sebagai berikut ( Nursalam, 2015 ) :

a) Status kesehatan dibandingkan dengan standar untuk menentukan kesenjangan.

b) Diagnosa keperawatan dihubungkan dengan penyebab kesenjangan dan pemenuhan kebutuhan pasien.

c) Diagnosa keperawatan dibuat sesuai dengan wewenang.

d) Komponen diagnosa terdiri atas PE/PES.

e) Pengkajian ulang dan revisi terhadap diagnosis berdasarkan data terbaru.

- Langkah - langkah menentukan diagnosa keperawatan menurut Setiadi (2012) sebagai berikut:

\section{a) Klasifikasi dan analisis data}

Klasifikasi atau memfokuskan data adalah mengelompokan data-data pasien atau keadaan tertentu dimana klien mengalami permasalahan kesehatan atau keperawatan berdasarkan kriteria permasalahannya.

Analisis data adalah kemampuan mengkaitkan data dan menghubungkan data tersebut dengan konsep teori dan prinsip yang relevan untuk membuat kesimpulan dalam menentukan masalah kesehatan dan keperawatan pasien.

Cara analisis data adalah:
(1) Validasi data, meneliti kembali data yang terkumpul.

(2) Mengelompokkan data berdasarkan kebutuhan biopsiko-sosial dan spiritual.

(3) Membandingkan dengan standar.

(4) Membuat kesimpulan tentang kesenjangan yang ditemukan.

\section{b) Interpretasi data}

(1) Menentukan kelebihan pasien.

Jika pasien memenuhi standar kriteria kesehatan, perawat akan menyimpulkan bahwa pasien memiliki kelebihan dalam hal tertentu dan kelebihan ini dapat digunakan untuk membantu menyelesaikan permasalahan pasien.

(2) Menentukan masalah pasien/ menyimpulkan.

Jika pasien tidak memenuhi standar kriteria kesehatan maka pasien tersebut mengalami keterbatasan dalam aspek kesehatannya dan memerlukan pertolongan.

(3) Menentukan masalah pasien yang pernah dialami, tahap ini perawat menentukan masalah potensial pasien.

(4) Penentuan keputusan.

(a) Tidak ada masalah tetapi perlu peningkatan status dan fungsi (kesejahteraan) : tidak ada indikasi respon perawat, meningkatnya status kesehatan, adanya inisiatif promosi kesehatan. 
(b) Masalah kemungkinan.

Pola mengumpulkan data untuk memastikan ada atau tidaknya masalah yang diduga.

(c) Masalah aktual atau risiko.

Pasien tidak mampu merawat karena pasien menolak masalah dan pengobatan.

(d) Masalah kolaboratif.

Konsultasikan dengan tenaga kesehatan profesional yang kompeten dan bekerja secara kolaboratif pada masalah tersebut.

\section{c) Validasi data}

Pada tahap ini perawat memvalidasi data yang ada secara akurat yang dilakukan bersama pasien dan keluarga atau masyarakat. Validasi ini dilaksanakan dengan mengajukan pertanyaan yang reflekif kepada pasien atau keluarga tentang kejelasan interpretasi data.

\section{d) Merumuskan diagnosa keperawatan}

Perumusan diagnosa keperawatan didasarkan pada identifikasi masalah dan kemungkinan penyebab. Selain itu perumusan diagnosa juga sesuai dengan kebutuhan pasien.

- Komponen diagnosa keperawatan menurut Dermawan (2012) sebagai berikut:

\section{a) Problem}

Problem adalah gambaran keadaan pasien dimana tindakan keperawatan dapat diberikan. Masalah atau problem adalah kesenjangan atau penyimpangan dari keadaan normal yang seharusnya tidak terjadi. Tujuan : menjelaskan status kesehatan pasien secara jelas dan sesingkat mungkin. Diagnosis keperawatan disusun dengan menggunakan standart yang telah disepakati, supaya :

(1) Perawat dapat berkomunikasi dengan istilah yang dimengerti secara umum.

(2) Memfasilitasi dan mengakses diagnosa keperawata

(3) Sebagai metode untuk mengidentifikasi perbedaan masalah keperawatan dengan masalah medis.

(4) Meningkatkan kerjasama perawat dalam mendefinisikan diagnosis dari data pengkajian dan intervensi keperawatan.

\section{b) Etiologi}

Etiologi atau faktor penyebab adalah faktor klinik dan personal yang dapat merubah status kesehatan atau mempengaruhi perkembangan masalah. Merupakan pedoman untuk merumuskan intervensi. Unsur - unsur dalam identifikasi etiologi meliputi unsur PSMM : 
(1) Patofisiologi penyakit : semua proses penyakit, akut atau kronis yang dapat menyebabkan atau mendukung masalah.

(2) Situasional : personal dan lingkungan (kurang pengetahuan, isolasi sosial).

(3) Medikasi (berhubungan dengan program perawatan atau pengobatan) : keterbatasan institusi atau rumah sakit, sehingga tidak mampu memberikan perawatan.

(4) Maturasional : adolensent (ketergantungan dalam kelompok), young adult (menikah, hamil, menjadi orang tua), dewasa (tekanan karier).

\section{c) Sign and symptom}

Data subyektif dan obyektif yang ditemukan sebagai komponen pendukung terhadap diagnosa keperawatan. Sign and symptom (tanda dan gejala) adalah ciri, tanda atau gejala yang merupakan informasi yang diperlukan untuk merumuskan diagnosa keperawatan.

- Tipe diagnosa keperawatan menurut Carpenito (2009) sebagai berikut:

\section{a) Diagnosa keperawatan aktual.}

Diagnosa keperawatan aktual adalah diagnosa menjelaskan masalah yang nyata terjadi saat ini. Pada diagnosa keperawatan aktual batasan karakteristiknya adalah tanda dan gejala yang bila terlihat dalam waktu yang sama mewakili diagnosa keperawatan.
Batasan karakteristik dibedakan menjadi karakteristik mayor dan minor. Mayor setidaknya satu tanda harus ada untuk validasi diagnosa, minor mendukung bukti tetapi boleh tidak ada.

\section{b) Diagnosa keperawatan risiko.}

Diagnosa keperawatan risiko adalah keputusan klinis yang divalidasi oleh faktor risiko. Tidak terdapat tanda dan gejala mayor.

\section{c) Diagnosa keperawatan potensial.}

Diagnosa keperawatan potensial adalah diagnosa yang didasarkan atas kondisi sehat klien untuk mencapai tingkat kesehatan yang lebih tinggi.

\section{d) Diagnosa keperawatan kemungkinan.}

Diagnosa keperawatan kemungkinan adalah pernyataan tentang masalah yang diduga akan terjadi, masih memerlukan data tambahan.

\section{e) Diagnosa keperawatan sindroma}

Diagnosa keperawatan sindroma adalah sekelompok atau kumpulan dari beberapa diagnosa keperawatan yang terjadi secara bersamaan yang memiliki penyebab tunggal.

\section{PENUTUP}

\section{KESIMPULAN}

Diagnosa keperawatan merupakan suatu kesimpulan yang dihasilkan dari analisa data 
(Carpenito, 2009). Diagnosa keperawatan adalah langkah kedua dari proses keperawatan yang menggambarkan penilaian klinis tentang respon individu, keluarga, kelompok maupun masyarakat terhadap permasalahan kesehatan baik aktual maupun potensial. Penegakan diagnosis keperawatan sebagai salah satu komponen standar asuhan keperawatan perlu dilaksanakan dengan baik sebagaimana yang diamanahkan dalam undang-undang No.38 tahun 2014 tantang keperawatan pada pasal 30 bahwa dalam menjalankan tugas sebagai pemberi asuhan keperawatan, perawat berwenang menetapkan diagnosis keperawatan.

\section{SARAN}

Dalam menentukan diagnosa keperawatan harus dengan benar dan tetap sesuai dengan pemahaman perawat mengenai diagnosa keperawatan, maka dari itu pemahaman perawat mengenai diagnosa keperawatan harus ditingkatkan. Mulai dari mencari tahu bagaimana langkah-langkah diagnosa keperawatan tipe dan juga jenis diagnosa keperawatan.

\section{DAFTAR PUSTAKA}

Apriyani, H. (2015). IDENTIFIKASI DIAGNOSIS KEPERAWATAN PADA
PASIEN DI RUANG PARU SEBUAH RUMAH SAKIT. Jurnal Keperawatan. ISSN 1907 - 0357. 11(1). 107 -111.

Damhudi, D., Irawaty, D., Hariyati, R. S. (2012). Efektifitas Metode NIHSS dan ESS Dalam Membuat Diagnosa Keperawatan Aktual Pada Pasien Stroke Berat Fase Akut. Jurnal Keperawatan Indonesia, 7-12.

Dewi, I.P. Nurrohmah. Fadlurrahman, F.R. (2020). Analisis Pengetahuan Perawat dalam Menentukan Diagnosis Asuhan Keperawatan. Jurnal Ilmiah Keperawatan Indonesia. ISSN: 2580-3077. 4(1). 73-87.

Hidayah, N. (2014). Manajemen Model Asuhan Keperawatan Profesional (MAKP) Tim Dalam Peningkatan Kepuasan Pasien Di Rumah Sakit. Jurnal Kesehatan. 410-426. M. Rofi'i. Warsito, B.E. Santoso, A. Ulliya, S. (2018). Diagnosa Keperawatan Yang Sering Ditegakkan Perawat Pada Pasien Tuberkulosis Paru Di Rumah Sakit. Jurnal Kepemimpinan dan Manajemen Keperawatan. 1(2). 1-8.

Nanda. (2012). Nursing Diagnoses Definitions and Classifications. Oxford: Wiley-Blackwell 
Novieastari, Enie. (2010). Diagnosa Keperawatan Sejahtera. Jurnal Keperawatan Indonesia. 7(2).

Nurhesti, P.O.Y. Prapti, N.K.G. Kamayani, M.O.A. Suryawan, P.A. (2020). ANALISIS PENGGUNAAN DIAGNOSIS KEPERAWATAN BERBASIS SDKI DAN NANDA. Community of Publishing In Nursing (COPING), p-ISSN 2303-1298, eISSN 2715-1980. 8(2). 118-123.

Simamora, R. H., Bukit, E., Purba, J. M., \& Siahaan, J. (2017). Penguatan kinerja perawat dalam pemberian asuhan keperawatan melalui pelatihan ronde keperawatan di rumah sakit royal prima medan. Jurnal pengabdian kepada masyarakat, 23(2), 300-304.

Simamora, R. H. (2019). Socialization of Information Technology Utilization and Knowledge of Information System Effectiveness at Hospital Nurses in Medan, North Sumatra. Editorial Preface From the Desk of Managing Editor..., 10(9).

Suryono, Nugroho, C. (2020). Kompetensi Perawat Mendokumentasikan Diagnosis Keperawatan Berdasarkan Standar Diagnosis Keperawatan Indonesia (SDKI). Jurnal ILKES (Jurnal Ilmu Kesehatan). 11(1). 233-238.
Wirdah, H. (2016). Penerapan Asuhan Keperawatan Oleh Perawat Pelaksana di Rumah Sakit Banda Aceh. Jurnal Ilmiah Mahasiswa Fakultas Keperawatan. 1. 1-6. 